\title{
Homage to Prof. Dr. Othmar Schubiger, elected as Honorary Member of ESNR 2009
}

\author{
M. Leonardi • G. Wilms
}

Published online: 21 November 2009

(C) Springer-Verlag 2009

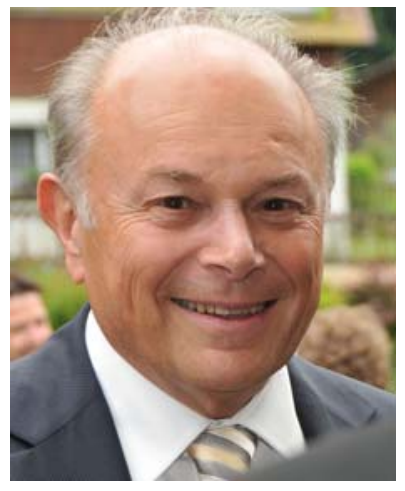

Othmar Schubiger was born in 1942 in Degersheim, a village near St-Gallen in Switserland, as the son of a country general practitioner. After finishing his medical school at the University of Zürich in 1969, he became a resident at the University Hospitals of Zürich and trained consecutively one year in Pathology, Radiology and Surgery. He then definitively chose for Radiology and Neuroradiology for the three following years. After an additional year of training in Radiotherapy and Nuclear Medecine as was the custom in these years, he settled as a Senior physician in Neuroradiology at the University Hospitals In Zürich. During the following years he

\footnotetext{
M. Leonardi $(\bowtie)$

Bellaria Hospital, Bologna University,

Via Altura, 3,

40139 Bologna, Italy

e-mail: marco.leonardi@centauro.it

G. Wilms

Afdeling Radiologie, UZ Gasthuisberg,

Herestraat 49,

3000 Leuven, Belgium

e-mail: guido.wilms@uz.kuleuven.ac.be
}

followed several one month visiting fellowships in different neuroradiological departments in Europe and the USA such as those of Prof. René Djindjan in Paris, Prof.Jacqueline Vignaud in Paris and Prof. Hans Newton in San Francisco.

From 1980 to 1986 he was Chief Physician of Neuroradiology in the Cantonal Hospital of Aarau. In 1986 he was finally installed as Chief physician of the Neuroradiological and Radiological Institute of the AMI-Klinik Im Park that later became Hirslanden-Klinik Im Park in Zürich.

Othmar Schubiger then developed an impressive academic $\mathrm{CV}$ with more then 80 publications in national and international radiological and neuroradiological journals, with more then 40 of them as a first author, mostly on neuroradiology of the pituitary gland, the spine and general diagnostic neuroradiological topics. He also wrote a book on "Die Computertomographie der Wirbelsäule" and coedited with Anton Valavanis and Tom Naidich the book "Clinical Imaging of the Cerebellopontine Angle".

$\mathrm{He}$ is founding member of the Swiss Society of Neuroradiology, where he served several offices as treasurer, president and actually past-president and of the European Society of Head and Neck Radiology. He is member of the German, Austrian, European and American Society of Neuroradiology.

Othmar Schubiger was elected as the Treasurer of the European Society of Neuroradiology during the XIXth annual congress of the ESNR in Bruges in 1993. As such he served for 4 consecutive terms up to 2006. During all these years Othmar Schubiger practiced his office with enthusiasm and dedication. Together with the central secretariat he followed the evolution of the membership and took care of the financial health of the society by insisting on correct and punctual payment of the annual membership fees. Above all though, Othmar Schubiger was 
an active member of the board of the ESNR. He assisted at almost all the meetings of the board during this 13-year period and assured, together with the Secretary-General the continuity in the Society. He was active in the many discussions that aimed at improving the position and the strength of the ESNR within Europe and the world, and took part in essential decisions of the board of the ESNR. As the ex-officio treasurer of the temporary European Board of Neuroradiology, he was the co-author of the new European Course in Neuroradiology and of the Divison of
Neuroradiology of the Section Radiology of the UEMS. Above all, for all the officers of the ESNR that were part of the Executive Committee together with Othmar during so many many years, his kindness and his warm personality made him a special reference and a great example. Therefore for many of us he became a true friend for life.

Othmar Schubiger deserves the honorary membership of the ESNR for his outstanding clinical and scientific curriculum as a European Neuroradiologist, but above all for the tremendous work he did during so many years for the ESNR. 